\title{
GAMBARAN KEPATUHAN MINUM OBAT ANTIRETROVIRAL (ARV) PADA ORANG DENGAN HIV AIDS DI PUSKESMAS WEDOMU KABUPATEN BELU NUSA TENGGARA TIMUR
}

\author{
Fransiskus Tae*) \\ Elfrida Dana F. Riwoe Rohi*) \\ Pius A.L.Berek*) \\ ${ }^{*}$ Program Studi Keperawatan Universitas Timor, Kampus Atambua, Jalan Wehor Kabuna \\ Haliwen, Atambua, Nusa Tenggara Timur, post 85711. Phone : 081339361065. Email : \\ franstaekore86@gmail.com
}

\begin{abstract}
ABSTRAK
Kepatuhan dalam meminum ARV merupakan factor terpenting dalam menekan jumlah virus HIV dalam tubuh manusia. Penekanan jumlah virus yang lama dan stabil bertujuan agar system tubuh imun tetap terjaga. Dengan demikian, orang yang terinfeksi virus HIV akan mendapatkan kualitas hidup yang baik dan juga mencegah terjadinya kesakitan dan kematian. Tujuan dari penelitian ini adalah untuk mengidentifikasi kepatuhan minum obat antiretroviral ( ARV ) pada orang dengan HIV / AIDS. Sampel sebanyak 16 responden yang memenuhi kriteria inklusi. Teknik pengambilan sampel dengan total sampling. Hasil penelitian ditemukan $87,5 \%$ responden memiliki kepatuhan tinggi dalam mengkonsumsi obat ARV, dan 12,5\% memiliki kepatuhan yang rendah. Disarankan agar pemegang program HIV / AIDS di puskesmas melakukan pendampingan yang optimal agar semakin meningkatkan tingkat kepatuhan pasien dalam mengkonsumsi obat ARV. Kepada peneliti selanjutnya supaya melakukan penelitian serupa dengan teknik mengobservasi penderita dalam konsumsi ARV sejak awal terapi, sambil follow up terhadap viral load dan CD4 pasien.
\end{abstract}

Kata Kunci $\quad$ : ARV, HIV / AIDS, Tingkat Kepatuhan

\section{DESCRIPTION OF COMPLIANCE CONSUMTION OF ANTIRETROVIRAL (ARV) MEDICATION IN PEOPLE LEAVING WITH HIV AIDS IN PUSKESMAS WEDOMU, BELU REGENCY, EAST NUSA TENGGARA}

\author{
Fransiskus Tae ${ }^{*}$ \\ Elfrida Dana F. Riwoe Rohi*) \\ Pius ALBerek*) \\ *)Nursing Program at University of Timor, Atambua Campus, Jl. Wehor Kabuna Haliwen, \\ Atambua, East Nusa Tenggara, post 85711 Phone: 081339361065. Email: \\ franstaekore86@gmail.com
}

Compliance in taking ARV is most important factor in reducing the amount of HIV virus in the human body. Emphasis on the number of viruses that are long and stable aims to keep the body's immune system awake. Thus, people infected with the HIV virus will get a good quality of life and also prevent the occurrence of pain and death. The purpose of this study was to identify compliance with antiretroviral (ARV) drugs in people with HIV / AIDS. Sampel is 16 respondents who met the inclusion criteria, with a total sampling. The results of the study found $87.5 \%$ of respondents had high adherence to taking ARV drugs, and $12.5 \%$ had low compliance. It is recommended that HIV / AIDS program holders be on Puskesmas conducts optimal assistance in order to increase the level of compliance of patients in taking ARV drugs. Later researchers conducted a study similar to the technique of observing patients taking antiretroviral drugs from the start, while following up on patients' viral load and CD4 cells.

Keywords

: ARV, HIV / AIDS, Compliance Level 


\section{PENDAHULUAN}

HIV/AIDS saat ini merupakan masalah kesehatan yang mengancam Indonesia dan banyak negara di seluruh dunia (WHO, 2015 dalam Era, 2016). HIV/AIDS adalah penyakit defisiensi imun sekunder yang paling umum terjadi di dunia dan sampai saat ini masih menjadi masalah epidemik dunia yang serius karena adanya peningkatan angka kejadian yang terus bertambah dari waktu ke waktu (Ignativicius dan Workman, 2010). Hal ini menunjukkan bahwa jumlah penderita HIV/AIDS di Indonesia yang sebenarnya belum diketahui secara pasti (Rokhmah dan Khoirun, 2013). Fenomena gunung es ini terjadi akibat penyebaran HIV/AIDS yang tidak dapat diprediksi akibat dari gaya hidup diantaranya perilaku seks bebas yang tidak terkontrol. Oleh karena itu penderita HIV/AIDS memerlukan pengobatan dengan Antiretroviral (ARV) untuk menurunkan jumlah virus HIV di dalam tubuh agar tidak masuk ke dalam stadium AIDS serta untuk mencegah terjadinya infeksi oportunistik dan komplikasinya (Kemenkes RI, 2014 dalam Era, 2016). Penderita yang mengkonsumsi obat antiretroviral (ARV) harus mengkonsumsinya seumur hidup, tepat waktu dan displin (dalam Era, 2016). Karena ARV adalah Obat yang dapat menekan perkembangan HIV dalam tubuh. ( Lestari et all, 2012 ).

Penyebaran HIV/AIDS sangat cepat di dunia, hingga akhir 2014 jumlah penderita orang dengan HIV/AIDS (ODHA) di dunia sebesar 36,9 juta orang. WHO mencatat sejak AIDS di temukan hingga akhir 2014 terdapat 34 juta orang meninggal dan di tahun 2014 juga tercatat sebesar 1,2 juta orang meninggal karena virus tersebut (Udiono at all, 2017). Berdasarkan data dari Kemenkes RI tahun 2014 penemuan kasus baru dengan jumlah penderita HIV 32.711 dan AIDS 7.864 penderita. Pada tahun 2015 terjadi penurunan penemuan kasus baru yaitu HIV sebanyak 30.935 penderita dan AIDS 6.37 penderita, namun hingga bulan Desember 2016 terjadi kenaikan kembali penemuan kasus HIV sebanyak 41.250 dan AIDS 7.491 penderita (Udiono at all, 2017). Berdasarkan data dari profil dinas kesehatan Kota Kupang, jumlah kasus HIV/AIDS dari tahun 2011 berjumlah 65 kasus namun sampai dengan tahun 2015 telah mencapai 783 kasus. Kasus banyak terjadi pada kelompok usia produktif yakni $25-34$ tahun. Dan berdasarkan data dari Dinas Kesehatan Kabupaten Belu : penderita HIV/AIDS di Kabupaten Belu sejak tahun 2013 hingga tahun 2018 bulan (Januari Maret) tercatat berjumlah 514 orang, Berdasarkan data perkecamatan adalah : Atambua Barat sebanyak 88 orang, Atambua Selatan 83 orang, Kakulukmesak 81 orang, Tasifeto Timur 65 orang, Kota Atambua 60 orang, Tasifeto Barat 55 orang, Raihat 10 orang, Lamaknen 29 orang, Lamaknen Selatan 9 Orang, Nanaetdubesi 11 orang, Lasiolat 7 orang. Berdasarkan World Health Organisation (WHO), menyebutkan terdapat 12.9 juta orang telah mendapatkan pengobatan ARV. Di seluruh dunia sampai akhir tahun 2013 tercatat 11.7 juta orang dari mereka yang berasal dari negara yang pendapatannya rendah. Penambahan 2 juta orang yang memulai pengobatan ARV pada tahun 2013 menandai penambahan penyediaan terbesar obat ARV untuk setiap tahunnya. Pada akhir tahun 2014, tercatat sebanyak 14,9 juta orang yang mendapatkan pengobaatan ARV dan pada tahun 2015, 15 juta orang yang akan mendapatkan pengobatan ARV di negara yang berpendapatan menengah ke bawah. (WHO, 2014 dalam Era, 2016). Selanjutnya (Fauk et al., 2018) dalam penelitiannya menemukan bahwa secara kualitatif pasien HIV / AIDS 
memiliki banyak keterbatasan pemahaman dan perasaan takut untuk memeriksakan diri, bahkan tidak percaya kepada tenaga kesehatan yang menyebabkan sulit untuk terbuka (Open Status) sehingga sebagian besar dari mereka mengalami kesulitan untuk mendapatkan terapi ARV.

Perlu kita ketahui bahwa HIV/AIDS adalah penyakit menular yang sangat membahayakan, oleh karena itu ODHA harus selalu patuh dalam minum obat ARV. Kepatuhan ODHA dalam minum obat ARV juga didasari adanya motivasi diri, dukungan dari keluarga, dukungan dari teman dan dari tenaga kesehatan. Melalui pengobatan ARV kualitas hidup ODHA semakin meningkat, dan adanya hubungan yang baik dengan penyedia perawatan kesehatan serta peran pendamping minum obat. Akan tetapi orang dengan HIV/AIDS biasanya tidak patuh dalam minum obat ARV itu karena adanya efek samping dari pada Obat ARV yaitu mual, demam, ruam ruam di kulit, rasa seperti orang mabuk sehingga orang dengan HIV/AIDS merasa jenuh untuk minum obat ARV (Lestari at all, 2010).

Cara paling efisien dan efektif untuk menaggulangi infeksi HIV/AIDS adalah dengan mengurangi penularan dari ibu ke anaknya, penularan melalui darah dan penularan melalui hubungan seks (Depkes RI, 2003). Selain itu, penanggulangan pada orang yang sudah terinfeksi HIV/AIDS adalah dengan pemberian obat ARV. Karena konsumsi ARV adalah seumur hidup maka perlu diperhatikan kepatuhan ODHA dalam mengkonsumsi ARV agar tidak resisten. Berdasarkan permasalahan di atas maka penulis merasa tertarik untuk melakukan penelitian dengan judul tentang "Gambaran kepatuhan minum obat Antiretroviral pada orang dengan HIV/AIDS di Puskesmas Wedomu

\section{METODOLOGI}

Penelitian ini merupakan penelitian kuantitatif deskripti dengan tujuan untuk mengidentifikasi gambaran kepatuhan minum obat ARV pada ODHA di Puskesmas Wedomu Kabupaten Belu Nusa Tenggara Timur. Teknik pengumpulan sampel dengan total sampling terhadap 16 orang responden, dengan kriteria inklusinya adalah Orang Dengan HIV/AIDS yang bersedia menjadi responden; Sudah melewati masa kritis; dan ODHA yang sementara menjalani terapi ARV sedangkan kriteria eksklusinya adalah tidak bersedia menjadi responden; ODHA yang tidak menjalani terapi ARV; dan Sedang dalam masa kritis. Alat yang digunakan adalah lembar observasi untuk mencatat kegiatan minum obat ARV. Analisa data menggunakan ketentuan DEPKES untuk menilai tingkat kepatuhan dengan kriteria penilaian sebagai berikut :

Tingkat Kepatuhan Tinggi $\geq 95 \%$

Tingkat Kepatuhan Sedang $80-90 \%$

Tingkat Kepatuhan Rendah < $80 \%$

\section{HASIL PENELITIAN}

a. Gambaran Umum Tempat Penelitian

UPTD Puskesmas Wedomu berdiri pada tahun 1974 di wilayah Desa Manleten, Kecamatan Tasifeto Timur, Kabupaten Belu, dengan cakupan wilayah kerjanya mencakup 8 Desa. Selanjutnya dalam perjalanan dilakukan penambahan sarana penunjang pelayanan yaitu puskesmas pembantu Dafala, PosKesDes Fatubaa, PosKesDes Boraktetuk, PosKesDes Asulait, PosKesDes Bauho, Polindes Sanabibi, polindes Takirin, 
Polindes Bauatok, Polindes Aitamaan, Polindes Tialai, dan Polindes Halimodok.

UPTD Puskesmas Wedomu

merupakan Puskesmas Rawat Jalan, terletak di Wilayah Desa Manleten, Kecamatan Tasifeto Timur, Kabupaten Belu, Provinsi Nusa Tenggara Timur, dengan luas tanah sebesar 30 x $45 \mathrm{~m} 2$. Jarak dari Puskesmas ke Ibu Kota Kabupaten $\pm 25 \mathrm{~km}$; jarak dengan Ibu Kota Provinsi $\pm 306 \mathrm{~km}$. Batas - batas wilayah kerja UPTD Puskesmas Wedomu sebagai berikut: Sebelah Utara berbatasan dengan Negara Demokrat Timor Leste, Sebelah Selatan berbatasan dengan Wilayah Kerja Puskesmas Halilulik, Sebelah Timur berbatasan dengan Wilayah Kerja Puskesmas Auliluk, Sebelah Barat berbatasan dengan Wilayah kerja Puskesmas Kota.

Wilayah Kerja UPTD Puskesmas Wedomu tersebar dalam 8 Desa yaitu : Desa Manleten dengan wilayah kerjanya sebesar 35,4 km2, Desa Takirin dengan wilayah kerjanya sebesaar 9,3 km2, Desa Dafala dengan wilayah kerjanya sebesar 19,7 km2, Desa Bauho dengan wilayah kerjanya sebesar 14,4 km2, Desa Halimodok dengan wilayah kerjanya sebsar 4,8 km2, Desa Sarabau dengan wwilayah kerjanya sebesar 6,6 km2, Desa Fatuba'a dengan wilayah kerjanya sebesar 34,0, Desa Tialai dengan wilayah kerjanya sebesar 10,0 km2, dan jumlah penduduknya di tahun 2018 sebesar 15.309 jiwa dari 7.591 KK.

\section{b. Karakteristik Responden}

Karakteristik responden meliputi Nama, umur, jenis kelamin, pendidikan, pekerjaan, 16 responden yang dipilih adalah pesien HIV/AIDS yang didiagnosa dan sedang menjalani pengobatan ARV pada bulan januari - juni 2019, dan pada saat penelitian pasien dinyatakan telah menjalani pengobatan ARV.

\section{Hasil Penelitian}

Penelitian ini dilakukan di Puskesmas Wedomu pada tanggal 25 Maret 2019 sampai dengan 25 April tahun 2019, dengan sampel yang berjumlah 16 responden yang menjawab kuesioner yang telah disebarkan pada saat melakukan penelitian ini. Tujuan dari penelitian adalah untuk mengetahui kepatuhan minum obat ARV pada orang dengan HIV/AIDS di Puskesmas Wedomu. Hasil dari penelitian ini adalah sebagai berikut.

Tabel 1

Distribusi Frekuensi

Responden Bedasarkan Jenis

Kelamin di Puskesmas

Wedomu ( $N$ : 16 )

\begin{tabular}{ccc}
\hline $\begin{array}{c}\text { Jenis } \\
\text { Kelamin }\end{array}$ & Frekuensi & $\begin{array}{c}\text { Persentase } \\
(\mathbf{\%})\end{array}$ \\
\hline Laki-Laki & 9 & 56,25 \\
Perempuan & 7 & 43,75 \\
\hline Total & $\mathbf{1 6}$ & $\mathbf{1 0 0}$ \\
\hline Sumber : Data Pimer, 2019 &
\end{tabular}

Berdasarkan Tabel 1 di atas dari 16 responden yang diteliti terdapat 9 orang $(56,25 \%)$ yang berjenis kelamin laki-laki dan 7 orang $(43,75$

$\%)$ berjenis kelamin perempuan.

Tabel 2

Distribusi Frekuensi

Responden Berdasarkan

Umur di puskesmas

Wedomu ( $N$ : 16 )

\begin{tabular}{ccc}
\hline Umur & Frekuensi & Persentase (\%) \\
\hline 15-24 Tahun & 4 & 25 \\
25-34 Tahun & 6 & 37,5
\end{tabular}




\begin{tabular}{ccc} 
35-44Tahun & 3 & 18.7 \\
45-54 Tahun & 3 & 18,7 \\
\hline Total & $\mathbf{1 6}$ & $\mathbf{1 0 0}$ \\
\hline & Sumber $:$ Data Primer, 2019
\end{tabular}

Dari tabel 2 di atas diketahui bahwa responden dalam penelitian ini adalah berumur 15-24 Tahun sebanyak 4 orang (25\%), umur 25-34 Tahun sebanyak 6 orang $(37,5 \%)$, umur 35-44 Tahun sebanyak 3 orang (18.7\%), umur 45-54 Tahun sebanyak 3 orang $(18,7 \%)$.

\section{Tabel 3}

Distribusi Frekuensi Responden Berdasarkan Tingkat Pendidkan di puskesmas Wedomu ( $\mathrm{N}: 16$ )

\begin{tabular}{ccc}
\hline $\begin{array}{c}\text { Tingkat } \\
\text { Pendidikan }\end{array}$ & Frekuensi & $\begin{array}{c}\text { Persentase } \\
(\mathbf{\%})\end{array}$ \\
\hline SD & 3 & 18,75 \\
SMP & 9 & 56,25 \\
SMA & 2 & 12,5 \\
Diploma / & 2 & 12,5 \\
Sarjana & \\
\hline Total & $\mathbf{1 6}$ & $\mathbf{1 0 0}$ \\
\hline \multicolumn{3}{r}{ Sumber : Data Primer, 2019 }
\end{tabular}

Berdasarkan tabel 3 dapat diketahui bahwa tingkat pendidikan dalam penelitian ini sebagian besar memiliki tingkat pendidikan SMP dengan jumlah sebanyak 9 orang $(56.25 \%)$, SD dengan Jumlah sebanyak 3 orang $(18,75)$ dan yang SMA sebanyak 2 orang (12,5\%). Sedangkan yang berpendidikan diploma/Sarjana adalah sebanyak 2 orang $(12.5 \%)$.
Tabel 4

Distribusi Frekuensi Responden Berdasarkan Pekerjaan di Puskesmas Wedomu ( $N$ : 16 )

\begin{tabular}{|c|c|c|}
\hline Pekerjaan & Frekuensi & $\begin{array}{c}\text { Persentase } \\
(\%)\end{array}$ \\
\hline Tidak Kerja & 2 & 12,5 \\
\hline Pelajar / & 1 & 6,25 \\
\hline \multicolumn{3}{|l|}{ Mahasiswa } \\
\hline Pegawai & 1 & 6,25 \\
\hline Wirausaha / & 4 & 25 \\
\hline \multicolumn{3}{|l|}{ Pedagang } \\
\hline IRT & 5 & 31,25 \\
\hline Lain - lain & 3 & 18,75 \\
\hline Total & 16 & 100 \\
\hline \multicolumn{3}{|c|}{ Sumber : Data Primer, 2019} \\
\hline $\begin{array}{l}\text { Dari tabel } \\
\text { kelompok respo } \\
\text { secara berturut } \\
\text { banyak sampai } \\
\text { kelompok IR' } \\
(31.25 \%) \text {, wirau } \\
4 \text { orang }(25 \%) \\
\text { orang }(18,75 \%) \\
\text { orang }(12,5 \%) \text {, } \\
(6,25 \%) \text {, pelaja }\end{array}$ & $\begin{array}{l}\text { s dapat dil } \\
\text { untuk jeni } \\
t \text { dari ya } \\
\text { paling sed } \\
\text { ebanyak } \\
\text { / pedagan } \\
\text { - lain s } \\
\text { k bekerja s } \\
\text { wai sebana } \\
\text { hasiswa (1 }\end{array}$ & $\begin{array}{l}\text { bahwa } \\
\text { kerjaan } \\
\text { paling } \\
\text { adalah } \\
\text { orang } \\
\text { banayk } \\
\text { nayk } 3 \\
\text { nayak } 2 \\
1 \text { orang } \\
\%) .\end{array}$ \\
\hline
\end{tabular}

Tabel 5

Distribusi Frekuensi Responden

Berdasarkan Status Kepatuhan di Puskesmas Wedomu ( N : 16 ) 


\begin{tabular}{ccc} 
Rendah & 2 & 12,5 \\
\hline Total & $\mathbf{1 6}$ & $\mathbf{1 0 0}$ \\
\hline \multicolumn{3}{c}{ Sumber $:$ Data Primer, 2019 }
\end{tabular}

Dari tabel diatas dapat dilihat bahwa sebagian besar responden dalam penelitian ini patuh terhadap pengobatan yaitu sebanyak 14 orang $(87,5 \%)$, tidak patuh 2 orang $(12,5 \%)$.

\section{PEMBAHASAN}

Penelitian ini bertujuan untuk mengetahui gambaran kepatuhan minum obat antiretroviral pada orang dengan HIV / AIDS di Puskessmas Wedomu. Berikut ini adalah pembahasan tingkat karakteristik menurut Jenis Kelamin yaitu dari 16 responden yang diteliti terdapat 9 orang $(56,25 \%)$ yang berjenis kelamin laki-laki dan 7 orang $(43,75 \%)$ berjenis kelamin perempuan, responden berjenis kelamin laki laki lebih banyak dari perempuan. Ada kemungkinan laki laki berpeluang menderita HIV / AIDS lebih besar daripada perempuan, penelitian ini tidak sesuai dengan yang dilakukan oleh Berek, dkk (2019) yang menemukan bahwa jenis kelamin laki laki hanya 39,6 $\%$ sedangkan terbanyak adalah perempuan sebanyak 60,4 \%. Adapun Berek, et al (2018) yang meneliti tentang hubungan antara umur dan jeniss kelamin dengan tingkat pengetahuan remaja tentang HIV / AIDS, dan ditemukan bahwa terdapat hubungan yang bermakna antara jenis kelamin dengan tingkat pengetahuan tentang HIV / AIDS. Dengan adanya pengetahuan yang baik maka akan menunjang kepatuhan untuk minum ARV secara teratur. Karakteristik menurut golongan umur yaitu dari 16 responden yang diteliti adalah berumur 15-24 Tahun sebanyak 4 orang (25\%), umur 25-34 Tahun sebanyak 6 orang $(37,5 \%)$, umur 35-44 Tahun sebanyak 3 orang (18.7\%), umur 45-54 Tahun sebanyak 3 orang $(18,7 \%)$. Berdasarkan kelompok umur tersebut, kelompok umur terbesar adaah 25 - 34 tahun yaitu sebesar 37,5 \%. Tingkat pendidikan yaitu SMP dengan jumlah sebanyak 9 orang $(56.25 \%)$, SD dengan Jumlah sebanyak 3 orang $(18,75)$ dan yang SMA sebanyak 2 orang (12,5\%). Sedangkan yang berpendidikan diploma/sarjana adalah sebanyak 2 orang (12.5\%). Untuk pekerjaan, kelompok IRT sebanyak 5 orang (31.25\%), wirausaha / pedagang sebanyakk 4 orang $(25 \%)$, lain lain sebanyak 3 orang $(18,75 \%)$, tidak bekerja sebanyak 2 orang $(12,5 \%)$, pegawai sebanyak 1 orang $(6,25 \%)$, pelajar / mahasiswa (12,5\%). Sedangkn berdasarkan tingkat kepatuhan hasil penelitian terhadap 16 responden di Puskesmas Wedomu ditemukan bahwa jumlah responden yang patuh terhadap pengobatan ARV lebih besar dibandingkan dengan responden yang tidak patuh. Responden yang patuh berjumlah 14 responden $(87,5 \%)$ sedangkan responden yang tidak patuh berjumlah 2 responden $(12,5 \%)$.

Hasil penelitian ini sesuai dengan hasil penelitian yang dilakukan oleh I Wayan Putu Sutrata, ett all dari Universitas Undayana pada 90 responden menunjukkan bahwa mayoritas responden yaitu sebanyak 70 orang $(77,80 \%)$ tergolong patuh. Selain itu, hasil penelitian yang dilakukan oleh Paul A.T Kawatu, ett all dari Universitas Sam Ratulangi Manado pada 62 responden menunjukkan bahwa mayoritas responden yaitu sebanyak 53 orang $(80,5 \%)$ tergolong patuh. Hal ini sesuai dengan teori yang dikemukanan Heri P (1999) bahwa kepatuhan merupakan suatu bentuk perilaku. Perilaku manusia berasal dari dorongan yang ada di dalam diri manusia, sedangkan dorongan 
merupakan usaha untuk memenuhi kebutuhan yang ada dalam diri manusia. (Heri P, 1999). Kepatuhan adalah minum obat sesuai dosis, tidak pernah lupa, tepat waktu, dan tidak pernah putus. Kepatuhan dalam meminum ARV mrupakan factor terpenting dalam menekan jumlah virus HIV dalam tubuh manusia. Penekanan jumlah virus yang lama dan stabil bertujuan agar system tubuh imun tetap terjaga tinggi. Dengan demikian, oraang yang terinfeksi virus HIV akan mendapatkan kualitas hidup yang baik dan juga mencegah terjadinya kesakitan dan kematian. Salah satu hal yang perlu dipahami dalam meningkatkan tingkat kepatuhan adalah pasien memerlukan dukungan, bukan disalahkan. (WHO, 2003). Namun, hasil penelitian ini juga didapatkan $12,5 \%$ ( $\mathrm{n}: 2$ ) yang tingkat kepatuhan rendah. Hal ini terjadi kemungkinan disebabkan oleh karena kedua responden tersebut mengalami alergi terhadap obat ARV yang di konsumsi, akibat imun yang tidak adekuat untuk mengkonsumsi obat ARV. Dengan demikian pengelola program HIV / AIDS dapat mempertimbangkan kelanjutan ARV pada kedua responden tersebut setelah dikonsultasikan dengan dokter pengelola HIV / AIDS di RSUD Mgr Gabriel Manek SVD ( Klinik VCT ). Hal ini bertujuan untuk memfasilitasi responden mendapatkan terapi ARV sesuai indikasi.

Berdasarkan fakta dan teori di atas dapat dijelaskan bahwa pengobatan ARV membutuhkan waktu yang lama, maka untuk menjadi seseorang yang patuh harus mmiliki keyakinan untuk sembuh dengan berobat secara teratur di samping adanya dukungan dari keluarga. Selain itu juga peneliti dapat menemukan kajian dari responden yaitu dengan adanya pengobatan ARV ini, terjadinya perubahan klinis pada respoden seeperti peningkataan berat badan responden, ekspresi responden semakin cerah dan tambah semangat sehingga responden yang patuh lebih banyak daripada yang tidak patuh karena responden ingin sembuh dari penyakit $\mathrm{HV}$ / AIDS.

\section{Keterbatasan}

Dalam penelitian ini ada beberapa keterbatasan yang dihadapi di antaranya:

1. Penulis menemukan kendala terkait kuisioner, dimana belum ada format baku untuk mengevaaluasi kepatuhan pasien minum ARV, sehingga peneliti menggunakan format atau kuisioner yang di kembangkan oleh peneliti terdahulu.

2. Penelitian ini menggunakan kuesioner (pertanyaan tertutup) sehingga responden hanya sebatas memilih jawaban yang tersedia, hal ini menyebabkan peneliti belum bisa mendapatkan data secara mendalam tentang (faktor - faktor yang mempengaruhi) tingkat kepatuhan pasien dalam pengobatan ARV di Puskesmas Wedomu.

3. Peneliti hanya mengobservasi dalam sebulan saja dan peneliti tidak melakukan pemantauan setiap hari namun dilakukan setiap minggu. Pemantauan setiap harinya hanya dilakukan dengan cara mnelpon responden.

\section{KESIMPULAN}

Berdasarkan hasil penelitian di atas tentang gambaran kepatuhan minum obat antiretroviral pada orang dengan HIV / AIDS dari 16 responden yang diteliti dapat disimpulkan bahwa terdapat 14 responden $(87,5 \%)$ yang patuh dan 2 responden $(12,5 \%)$ yang tidak patuh 
dalam menjalankan pengobatan ARV pada tahun 2019 di Puskesmas Wedomu. Disarankan agar dapat mengevaluasi tingkat kepatuhan pasien HIV / AIDS dalam pengobatan ARV, dan tetap follow up dua orang pasien yang tidak patuh dengan alasan alergi obat kemudian di anjurkan untuk mengkonsultasi ke klinik VCT dan dokter penanggung jawab untuk menggantikan terapi. Bagi peneliti selanjutnya agar mengembangkan penelitian serupa untuk menganalisis faktor-faktor yang mempengaruhi kepatuhan ODHA dalam mengkonsumsi obat ARV.

\section{KEPUSTAKAAN}

Berek, P. A. L., Be, M. F., Rua, Y. M., \& Anugrahini, C. (2018). Hubungan Jenis Kelamin dan Umur Dengan Tingkat Pengetahuan Remaja Tentang HIV/AIDS di SMAN 3 Atambua, Nusa Tenggara Timur. Jurnal Sahabat Keperawatan, 1, 1-13. Retrieved from https://jurnal.unimor.ac.id/JSK/article/v iew/85

Djoerban Zubairi. 2006. Buku Ajar Ilmu Penyakit Dalam. FKUI : Jakarta.

Dessy Era P. 2007. ADLN-Perpustakaan Universitas Airlangga.

Direktorat Jenderal Pemberantasan Penyakit Menular \& Penyehatan Lingkungan Departemen Kesehatan RI. 2003. Buku Pedoman Untuk Petugas Kesehatan Dan Petugas Lainnya. Jakarta.

Fauk, N. K., Sukmawati, A. S., Berek, P. A. L., Ernawati, Kristanti, E., Wardojo, S.
S. I., ... Mwanri, L. (2018). Barriers to HIV testing among male clients of female sex workers in Indonesia. International Journal for Equity in Health, 17(1), 1-10. http://doi.org/10.1186/s12939-0180782-4

Khasanah, Nur. 2011. Dampak Ekonomi, Sosial dan Psikologi HIV/AIDS pada Orang dengan HIV/AIDS (ODHA) di Kabupaten Kebumen. STIE Putra Bangsa Kebumen : Kebumen

Kuntari, et all. 2016. Umur Orang dengan HIV/AIDS (ODHA) berhubungan dengan tindakan pencegahan penularan HIV. FKUI : Depok.

Khoiron, Rohimah. 2013. Pengetahuan dan Sikap ODHA (Orang dengan HIV dan AIDS) tentang HIV dan AIDS dan Pencegahannya. FKM JUniversitas Jember : Jember.

Lestary Heny, et all. 2011. Gambaran Kepatuhan Orang Dengan HIVAIDS (ODHA) dalam minum obat ARV di kota Bandung, Provinsi Jawa Barat Tahun 2011-2012. Pusat Teknologi Intervensi Kesehatan Masyarakat : Bandung.

Mayon Whte, R.T, et all. 2006. Lecture Notes Penyakit Infeksi. Jakrta : Erlangga

Modul Pencegahan Dan Pengendalian HIV dan IMS di Indonesia. Dinas Kesehatan Provinsi Nusa Tenggara Timur. Kupang

Peraturan Menteri Kesehatan Republik Indonesia Nomor 87 Tahun 2014 
Tentang Pedoman Pengobatan Antiretroviral.

Ratnawati, Riska. 2017. Faktor-faktor yang mempengaruhi kepatuhan minum obat antiretroviral dikelompok Dukungan Sebaya Sehari Madiun. Prodi Kesehatan Masyrakat, STIKES Bhakti Husada Mulia Madiun : Madiun

Setiowulan, et all. 2012. Kapita Selekta Kedokteran. Jakarta : Media Auculapike

Widoyono. 2008. Penyakiyt Tropis Epidemiologi, Penularan, Pencegahan \& Pemberantasannya. Jakrta : Erlangga

Paul. A.T Kawatu, et all. 2014. Hubungn antara persepsi orang dengn HIV/AIDS (ODHA) Tentang Pengobatan HIV/AIDS dengan kepatuhan minum obat antiretroviral di Klinik Voluntary Counselling and Testing (VCT). Fakultas Kesehatan Msyarakat Univeritas Sam Ratulangi Manado : Manado

I Wayan Putu S.Y. 2017. Tingkat Kepatuhan Mengkonumsi Obat Antiretroviral dengan jumlah CD4 pada pasin HIV/AIDS di Klinik VCT RSUP Sanglan dalam periode September November 2014. Fakultas Kedokteran Universitas Undayana : Bali

Teguh H. Karyadi. 2016. Keberhasilan Pengoban Antiretroviral (ARV). Fakultas Kedokteran Universitas Indonesia : Jakarta.
Ully Adhi Mulyani, et all. 2013. Pemaknaan Obat Antiretroviral Bagi Sekelompok Orang Dengan HIV/AIDS di Kot Bandung, Cimahi, Denpasar dan Kabupaten Bandung. Bulein Penelitian Bidang Kesehatan : Jakarta. 